\title{
Unmasking Politics in the Niger Delta Narrative: Eco-Degradation and Activism in Tanure Ojaide's the Activist and Christie Watson's Tiny Sunbirds Far Away
}

\author{
Michael Ikenna Olughu \\ Department of English and Literary Studies, University of Nigeria, Nsukka, Nigeria
}

\begin{abstract}
The global outcry of ecological degradation by mankind has been the thematic focus in the creative oeuvres of writers and eco-critics in the literary domain as regards the degraded Niger Delta region of Nigeria and its consequent activism amongst her people. In view of the foregoing, this research in distancing itself from previous studies, seeks to examine the politics in the representation of ecological degradation and activism in the Niger settings of Tanure Ojaide's The Activist and Christie Watson's Tiny Sunbirds Far Away. Furthermore, this study equally examines points of similarities and differences within the dynamics of degradation of places and characters as well as resultant reactions among characters in both novels. This study deploys an eco-critical approach as its theoretical framework. Based on the findings of this study, it is evident that the unguided oil exploration activities by multinational oil companies as well as self-induced actions among characters spell doom on the environment as both living and non-living things become negatively affected in all ramifications. This study also reveals various forms of eco-activism ranging from radical, liberal, civil, conservative to revolutionary standpoints among characters in both texts. It is concluded that the two authors, though from different socio-cultural backgrounds used both texts as channels of creating global awareness towards promoting environmental conservation and various means of entrenching peace in the fictional devastated Niger Delta environment.
\end{abstract}

Keywords: Eco-degradation, Activism, Politics, Environment, Niger Delta Region

DOI: $10.7176 /$ JLLL/52-06

\section{Introduction}

The dominance and ignorant dispositions of human beings towards the life of the environment and its inhabitants has been generating passionate concern among writers all over the world. No doubt, the rationale behind this very concern is purely based on the common trend among humans and their perpetual exhibition of harmful activities which consequently lead to the devastation of both living and non-living beings in the environment. Suffice it to say that ecological degradation is a global phenomenon that centres on the depletion of natural resources through various inordinate attitudes of humans which usually triggers ecological activism towards instilling necessary core values and consciousness among people for the restoration of the environment from the shackles of human devastation. It is interesting to note that such activism being exhibited by the affected persons or characters are usually projected or manifested in radical, conservative and liberal manner as part of their struggle in the frontline of environmental healthiness and by extension, the safety of its inhabitants in general.

In the light of the above, topical issues of ecological degradation and its grave impacts on human and nonhuman beings as well as diverse manner of activism are evident in the Niger Delta region of Nigeria. This very region is blessed with oil as natural resources and has been exploited by multinational oil companies with its environment being devastated through oil exploration activities and other harmful human dispositions. Based on these unwholesome situations, there are a lot of struggles and violence among the Niger Delta people whose plights seem not to have received adequate attention by the concerned oil companies and the government in particular. This negligible condition, in no doubt has attracted a great deal of concern among ecocritics both within and outside Nigeria in exposing those worrisome issues affecting the region as regards its environment and people as thematic preoccupations in their various creative works. According to Onukaogu and Onyerionwu (2009:127), "one of the most momentous preoccupations of the Nigerian novel of the $21^{\text {st }}$ century is the Niger Delta crisis...some Nigerian critics [including non-Nigerians] consider the Niger Delta crisis as the biggest event available to Nigerian [world] literature as a subject matter". The above view of the duo is also in tandem with the position of an eminent scholar in Niger Delta studies, Alagoa (2011:vii), who admits that the "...analytical account of the Niger Delta question, has become a central element in the recent history of Nigeria, a story that has acquired an emotional tone in many narratives". To this end, Nwahunanya (2011: xvi) also observes that:

In a lot of writings from the Niger Delta, the social dislocation engendered by oil exploration are interrogated through the poetic, dramatic and fictional evocation of certain inherent contradictions that have featured in the physical and psychological landscape of the region...writers have through creative literature increased their pressures on sensitive minds in their calls for a dispassionate reconsideration of the environmental and human right issues 
which repeatedly constituted their thematic focus.

From the above observation, the place of writers and their oeuvres in engaging topical environmental issues in relation to the Niger Delta region is pivotal in all ramifications. This lends credence to the need for social commitment among writers and the use of their creative works in the words of Agbasiere for "the realization of society's aspirations and to the solution of societal problems" (2000:71). The interest of writers in interrogating ecological degradation and its impacts on the region and her people through fictional modes has been an inevitable cause. Thus, the use of literary outputs which abound in recent times with special interest on the Niger Delta environment towards creating environmental consciousness and awareness on the reading public by writers validates the view of Rueckert (1996:107) that "the intention of most ecologists [including ecocritics] is to find ways of keeping the human community from destroying the natural community...".

Based on the foregoing, this paper sets to apply an eco-critical approach which according to Glotfelty is the "study of the relationship between literature and the physical environment" (1996: xviii) in exploring nuances of despoiled environment and its aftermath as evident in Tanure Ojaide's The Activist and Christie Watson's Tiny Sunbirds Far Away. It is also designed to carry out a comparative examination of the representation of ecological degradation and its effects on the literary environment and characters as well as varied dimension of ecoactivism in both texts. Anchoring on these stated objectives, this paper equally argues that ecological degradation and activism are distinctive underlying issues that thrive in the Niger Delta setting of both novels.

\section{This is our Niger Delta Environment: Voice of an "Insider" in The Activist}

Ojaide's The Activist embodies vital thematic thrusts which centred on environmental praxis. Significantly, these thematic concerns on ecological explorations are fictional representation of the devastated Niger Delta region and its consequent crisis which have been attracting interest among writers and critics including him towards addressing the recurring anomalies in the region. The idea of Ngugi glaringly surfaces on the interest of Ojaide in X-raying vital issues that affect his Niger Delta environment and her people because "a writer responds with his total personality, to a social environment which changes all the time and being a sensitive needle, he registers with varying degrees of accuracy and successes of the conflicts and tensions in his changing society" (1972:47). It is interesting to note that The Activist captures exploitative and degrading activities of multinational oil companies especially the Bell Oil Company in respect to their oil exploration activities in the Niger Delta State. As a novel that focuses on the Niger Delta environment, it reveals the greediness of the oil companies and its unguided actions which result to the despoliation of the environment. The sense of greediness by the oil companies is exposed as the narrator accounts that, “...in the company's [Bell Oil Company] inordinate hunger for more barrels of oil to ship out to increase yearly record profits, the landscape was gradually turning into a wasteland. Residents of oil-producing area had become helpless before the monstrous power of their overlords, the oil company and the military government"(53). It can be deduced from the above account that the untold degradation of the Niger Delta environment is due to sheer greediness of the oil companies who are only interested in their own financial benefits in deriving great proceeds from the sale of oil drilled from the Niger Delta State in the Global market.

The novel presents utter despoliation of places through the activities of the oil companies which cause gradual extinction of both living and living things in the Niger Delta environment. There is evident pollution of water, land, and air which goes a long way to causing imbalance in the entire ecosystem. The narrator recounts the pitiable condition of the people of Niger Delta State as thus:

The air used to be cool because of constant rain and the luxuriant forest, but oil slicks, blowouts, and gas flares had destroyed that life. Even the rain that fell was so soot-black that no more did anybody drink rainwater, which, of all waters, used to be described as God-given water. The people had lost their green refuge as well. Their forests used to have deep green and lush foliage, the pride of the tropics, but had changed, since fires often followed oil and gas accidents. (82)

From the above account, it is obvious that the negative impacts of oil exploration activities are all encompassing, and as such affect lives of both human and non-human beings in the environment. Before the discovery of oil in the region, the environment seems to be free from any form of degradation and the people enjoy the natural way of living without any form of harmful exposure and abject poverty. Furthermore, the novel exposes the evil being orchestrated by the oil companies in the Niger Delta State using the romantic picnic of Ebi and her newly found love, the Activist who later became her husband. The trip by the duo on the Great River by the ocean exposes the high level of pollution of water by the oil exploration activities of Bell Oil Company in the region (101). The narrating voice presents the nostalgic memory of Ebi as regards the good old days when the environment has not been despoiled by crude oil. There is no gainsaying the fact that oil spillage has contributed to the pollution of the environment especially on water owing to recklessness on the side of the oil companies in the Niger Delta region. Furthermore, the narrator x-rays the true state of living of the local people and environment in the Niger Delta State. It expresses that: 
The Niger Delta was part of its people and just as the land, air and rivers were being poisoned so were the residents themselves, the Activist believed. He had observed in the short time since he had returned, the epidemics of dysentery and worm diseases that afflicted the people. The paradise of the olden days was degenerating fast into a kind of hell. The water that used to be an elixir had become poisonous brew. Something has to be done to detoxify the waters that fish could once more feel safe to breed there. (104)

Suffice it to say that the environmental injustices being meted by the oil companies on the Niger Delta State ignite ecological activism among the affected local people towards ensuring a free-polluted environment. In this regard, there are re (actions) which are exhibited against the degradation of the environment by some characters as events unfold in the novel. The protagonist, the Activist stands as the rallying point of activism in the novel. It is through his mission and revolutionary actions that other characters join forces with him in exposing and fighting the exploitation of the Niger Delta region by the oil companies and federal military government. The emergence and operations of the "Area Boys" becomes a paramount tool of the host community in fighting against the despoliation and exploitation of their environment and existing poor state of living among their people. The area boys constitute of vulnerable youths who have been affected socially or psychologically from the oil politics and pollution of their environment which give rise to a high level of poverty in their communities. It is worthy to state that the mode of operation of the area boys is very brutal ranging from stealing, kidnapping and incessant unleashing of violence in the region. The narrator expresses that "the area boys had their own story to tell, and, from their perspective, they were fighters attempting not only to reclaim what had been robbed from them but also holding firmly to what was theirs that others were attempting to snatch away.....They treated those who agreed with their robbers the same way they treated the robbers themselves" (55).

The Niger Delta State lacks various social amenities amidst the devastation of their environment. It is really a pathetic experience as members of the host oil producing communities in the novel languish in sickness, poverty and hopeless living. Regrettably, numerous members of the host communities are denied job opportunities even as a mere compensation to salvage their condition. Rather, people outside the region are being employed by the oil companies to do the work which is domiciled in their own environment amidst utter degradation. The novel brings to limelight Pere's sense of activism against the pitiable and exploitative machination of the Bell Oil Company and military government. He engages in various illicit actions which actually lead to breaking down of law and order in the Niger Delta State. In the course of fighting against the oil companies, Pere alongside the Activist engage in oil bunkering as a reprisal attitude in slowing the progress of oil exploration activities. It is interesting to note that oil bunkering is not limited to the strategy deployed by the host communities to frustrate the activities of the Bell Oil Company. Pere's engagement in oil bunkering is ideologically inclined. He sees such dubious activity as part of the germane strategy to reclaiming the natural resources which the Bell Oil Company has been exploiting to the detriment of his people (152). Pere and the Activist engage in oil bunkering and use the proceeds from the business in establishing a firm called 'Delta Cartel' which helps in harnessing the cause of the Niger Delta people.

It is very pertinent to note that the sense of activism in the novel also manifests on the life of Chief Tobi Ishaka who is an epitome of truth. He acknowledges that his people are being short-changed in the oil wealth by both the Bell Oil Company and military government. Among other members of the traditional cabinet, he was the only one in the council of chiefs that sees the change in their environment as being negative in all ramifications. He vehemently, in many occasions, expresses his displeasure on the impacts of oil exploration activities being carried out by the oil companies which affect the major means of survival causing higher level of psychological alienation among his people. He believes that although the crude oil, with which the Niger Delta State is blessed with, brings wealth but the peoples' sources of livelihood as farmers and fishermen are very fundamental for quality conservation. Based on this worrisome condition of the Niger Delta State, Chief Ishaka sees the importance of education as a means of turning things around for positivity in his community. The narrator captures that, "Ishaka was one of the few chiefs with only one wife and blessed with five male children, all of them in school. He understood the importance of education, which, he told the other chiefs, would be the key to success in the future" (142). Considering Ishaka's idea that education is one of the major channels of activism against the degradation of the Niger Delta environment, he encourages his son, Dennis, to study petroleum engineering with the intention to occupying same position as the white in future towards drilling of oil in his farmland.

Furthermore, the intersection of academics, students and area boys in the vanguard of activism against the despoliation and exploitation in the Niger Delta State is quite glaring in the novel. This is owing to the potency of their solid approaches with diverse and diplomatic abilities which they possess as enlightened and radical groups. Nevertheless, there is a merger of different characters including the Activist, Omagbemi, Pere and the area boys. The idea behind this synergy is championed by Pere so as to ensure a swift progress of the exploited local people towards putting up a good fight against the Bell Oil Company and the military government (213). Obviously, the Activist charges the atmosphere of activism in the novel as he influences the likes of Omagbemi in the campus of the Niger Delta University through his public lectures. Of great importance is the role of 
Omagbemi in using his office as the President of Student Union to protesting against the despoliation of the environment. He believes as a concerned citizen and student per see, that the student union serves as a better platform to fight against the prejudiced activities of Bell Oil Company and the military junta in the Niger Delta State.

One of the striking incidents of activism in the novel also revolves around the role of women in the fight against the degradation of their environment by the Bell Oil Company. Ebi's interest to champion unity among the ethnic groups is shown mightily in her diplomatic steps which turn a great change in the entire desire of the Niger Delta people especially women to championing a just goal. While in the refugee camp, she and Mrs. Timi Taylor started a reconciliation process of uniting the entire ethnic groups in the Niger Delta region into fighting a common cause. They assemble the women and enlighten them on the need to protest against the Bell Oil Company whose activities have hampered their environment and way of life. They unanimously initiated Women for Delta Forum (WODEFOR) to fight against the oil company and the degradation of their environment especially on womanhood. It is worthy of note that the Activist is the spearhead of activism in the novel. He employs veritable tools to fight against the destruction of the environment through oil exploration activities of oil companies alongside military rule in Niger Delta State. One of the tools is the establishment of newspaper outlet, 'The Patriot' through the proceeds of oil bunkering activities of Delta Cartel. Nevertheless, The Patriot serves as a platform that significantly projects the high level of global attention that the Niger Delta environment and her people deserve amidst ecological degradation by the harmful activities of the oil companies. Omagbemi and Ebi run different editorials in 'The Patriot' by exposing the evils in their environment and the negligence by the military government which gives rise to the need for democratic governance in the Niger Delta State. The struggle for political power is another vital means of activism against the degradation and exploitation of the Niger Delta environment and her people by the Bell Oil Company and military government. Ojaide presents the Activist as a revolutionary character who sees the need for democracy and its principles as the only means of putting to an end to the pollution of the environment and exploitation of the Niger Delta people. The Activist contested for the Governorship position of the Niger Delta State and won by the people's trust in support of his mission towards restoring their degraded environment. The narrator accounts thus, "The Activist brought major changes to the State government....He created a Ministry of Environmental and Mineral Matters to deal with many of the problems of the Niger Delta...that the state needed to harness its natural resources and also to clean the polluted soil, water, and the air and put out fires from gas flares and oil blowouts" (344) which promote the safety of the Niger Delta State.

\section{Beyond "our Niger Delta Environment": Voice of an "Outsider" in Tiny Sunbirds Far Away}

Watson's Tiny Sunbirds Far Away is an interesting piece that equally exposes the nuances of degradation and its catastrophic effects on places and characters which results to various means of activism among the local people of oil producing communities. The novel is set in a typical Niger Delta environment. Watson as a British writer explores some vital environmental issues with a special eye on the Niger Delta region of Nigeria. Evidently, the first exposure of ecological degradation and its grave impacts on places and characters in the novel is made manifest on the eve of the planned return of Blessing and Ezekiel alongside Mama after their father left them for another woman who he impregnated out of wedlock. The harsh condition that follows this divorce makes the trio to migrate from the luxurious city of Lagos to their maternal Grandparents' house in a small village near Warri. The idea of Mama in relocating the family to her parents' village in the Niger Delta region is stubbornly greeted by Ezekiel over what he sees as a 'suicide mission' considering his (pre) informed knowledge over the devastated condition of the region. The narrating voice accounts thus:

Even if you did make up,' Ezekiel said, 'Warri is not safe. And those villages are even worse! Swamp villages! I googled Warri at the internet cafe. Oil bunkering, hostage taking, illness, guns, and poverty. What about my asthma? They burn poisonous chemicals straight into the air! It's not a safe place to live....It's dangerous. The whole Delta region. And if we don't get shot, the bacteria and parasite will surely kill us.' Ezekiel shook his head, and disappeared to his bedroom. (8)

This expression of anxiety by Ezekiel brings to limelight the terrible condition of the Niger Delta region of the novel. The oil exploration activities in the region being carried out by the Western Oil Company give rise to utter degradation of the environment. Mostly, such degradation as a result of oil spillage, gas flaring, blowouts among others, affect both living and non-living things in the ecosystem. The narrator traces the journey of Blessing, Ezekiel and Mama moving from Lagos to the Niger Delta region. This particular journey marks the encounter of the exploitation, devastation and actions of many characters in exposing various environmental injustices being perpetuated by the oil company and military government in the environment. The narrator accounts that:

As we neared Warri, the sky became even brighter. I saw a flame in the distance. A giant torch which made the sky look angry...'pipeline fires, 'said Zafi. 'They are burning the gases from 
the oil.' He started coughing again....Warri even smelled different from Lagos. I closed my eyes and sniffed. The air smelled like a book unopened for a very long time, and smoky as though the ground had been on fire. (12)

There is no gainsaying the fact that there is a high level of pollution by the activities of Western Oil Company which affects the water in the region. It is evident that oil spillage on waters goes a long way in affecting its maximum utilization and beneficiaries therein. The aquatic beings suffer mightily as they are being decimated as a result of contamination of their abode with poisonous chemicals. Blessing expresses that:

As Grandma led me away from the stink of the toilet a new smell reached my nose....'But we must not drink this. Only in emergencies.... But now, this water is full of oil, and salt, so only for washing clothes and bodies. Not for drinking.' ....The water was dark, dark, dark. It looked like thick mud. Swirly patterns coloured the top. I could not see the reflection of the strange twisted trees. I peered in, half closing my eyes, but there were no reflections. Not mine. Not even Grandma's....the river smelled like Warri, of old books that had been left in the rains. (20-21)

This exposure by Blessing shows a total pollution of the river in the Niger Delta region based on the effect of oil spillage. Thus, the continuous and unhealthy activities of Western Oil Company which lead to pollution of river also brings about dangerous pattern of existence among the people in the region including fishes and other aquatic organisms which are being decimated. In extreme cases, the people cannot depend on such water for drinking. This brings about lack of utilization of essential needs of man in the region which water is part of. One begins to wonder the fate of the people whose major occupation is fishing amidst the pollution of the river and drastic dead of fishes. It is crucial to note that the despoliation of the Niger Delta environment spurs insecurity and violence in the region from both the oil companies and host communities who are facing exploitation from the former. The exploited local people of the host communities employ rascality in fighting against the oil operatives as retaliation over injustices being meted on them and their environment by the Western Oil Company. The region is thrown into a chaotic condition which ushers in massive killings, kidnapping and other harmful activities. Even the white operatives are unsafe as the host community is thrown into a state of brutality and disintegration. The vulnerable youths take laws into their hands as a means of activism and resistance against the Western Oil Company and their harmful activities in the Niger Delta environment. The white operatives always get into armoured vans with police escorts which take them back to their locked compounds (38). This brings to limelight the level of insecurity in the region due to the amount of exploitation and degradation from the side of the oil company. Furthermore, the novel also presents unguided actions of some characters who are members of the host community towards the despoliation of their environment. Based on this revelation of the Niger Delta environment in the novel, Olughu (2018: 66) strongly argues thus:

Watson is quite objective in her representation of the devastation of the Niger Delta environment which many critics only concentrate on the pollution of the environment by the oil companies thereby shying away from other contributing actions of the local people. This biased approach of many sympathetic writers confirms the sentiment in the narratives of the Niger Delta environment in their creative oeuvres.

From the above argument, there is need to examine the possible roles of the local people in the host communities aside the activities of the oil companies in degrading their environment in the novel. In this regard, the narrator expresses:

I followed Grandma and Celestine to the area at the side of the toilet where the rubbish was held until the rains came to wash it down the river. Things were already pilling up. Plastic, wire, metal cans, and broken bottles. They rustled when we arrived. Grandma had told me they saved it all every year, then god washed it away. I wondered where the rubbish ended up, and who lived at the end of the river. (58)

This excerpt shows crudeness of the Niger Delta people in their violent actions against their own environment. Most times, these actions are justified on the basis of religious and superstitious beliefs. Obviously, the washing down of rubbish like plastic, wire, cans and broken bottles inside the river not only pollute the river, it affects the life span of fish and other aquatic organisms in the water. This uncultured manner of despoliation of the river is also confirmatory in the conversation between Blessing and Ezekiel. Blessing confides in the latter that, "she [Grandma] told me that witches and wizards were thrown into the river after they had died which was the reason not to drink the river water" (69). To this end, the throwing of dead bodies into the river by the local people is quite disgusting in all ramifications. This superstitious practice, in no doubt, pollutes the water and makes it unhealthy for people to drink and cook with it. In other words, the health condition of the people is questionable under this self-inflicted condition by the indigenes alongside adverse impacts of oil exploration activities in the novel.

Furthermore, Watson presents the devastation of tress in the environment through actions of the local people. This scenario manifests in one of Alhaji's wives, Celestine, who out of sheer ignorance wanted to destroy the life of trees in her immediate environment. She raised herself up high and suddenly jumped into the 
air, landing on a mango tree. It shook and bent over as if it was leaning down to pick something from the ground (88). This unrefined action of Celestine is discouraged by environmentally conscious character of Alhaji in reacting against any form of human injustices as regards the live of trees in the environment. He sees the need to preserve the environment especially trees at all cost. In same wake of interest, Alhaji's perspective on the restoration of the despoiled Niger Delta environment from the shackles of oil exploration activities of the Western Oil Company is quite pragmatic and liberal in nature. In this regard, Watson projects the need to have guidelines by the oil companies to guide their activities in the Niger Delta region as one of the safety measures in order to avoid polluting the environment (90). Alhaji exposes what amounts to the genesis of the degradation of the environment which ranges from lack of assumed experience among the oil engineers to no clear-cut protocols in ensuring the safety of the Niger Delta region. Significantly, Tiny Sunbirds Far Away clearly shows the impact of ecological degradation on the psychology and innocence of vulnerable youths in an environment. They engage in all manner of unethical living owing to the degradation of their environment which ignites aggression in their mode of existence. They imbibe immoral pattern of living like smoking of cigarettes and drinking to stupor as a result of environmental degradation (105). The need to put to an end to the exploitation and degradation of their environment by the Western Oil Company, form the centre of activism among the boys in the oil producing communities in forming a strong force against the former. This gives rise to total breakdown of law and order in the Niger Delta region (110-111). Although their actions are illicit but the actual interest is to offstage the white exploiters who have done more harm to their environment and sources of livelihood.

In lending more credence to other dimension of despoliation of the Niger Delta environment, the novel also presents sheer ignorance by the local people which overtly leads to the pollution of air with grave effects on the lives of human beings in the environment. One begins to wonder why fire should be built outside the village without any person within to control it in case of unforeseen circumstances. The impact of undue burning of fire affects the nutrient and fertility of the soil. The worst of it all is the disposition of Grandma in polluting the air by throwing rotten and infected afterbirth in the burning fire (114). This shows utter negligence by humans in polluting the environment without considering the implication attached to such hazardous actions. The burning of rotten afterbirth by Grandma who is a birth attendant has the tendency of causing total health hazard among people when inhale air with such poisonous substance in the environment. In the light of several means of degradation of the environment by both the local people and Western Oil Company, Watson exposes the high level of violence as a consequent result that bedevils the Niger Delta environment. The degradation of the region by the oil company gives rise to bitterness, aggression and mayhem from the local people in retaliation against the former and their exploitative dispositions. The activism among the local people breeds violence and massive killings on the side of both the oil company and 'Sibeye boys' who are set to frustrating the progress of the former against exploitation and despoliation of their environment (117). The activities of the Sibeye boys are geared towards fighting the exploitative oil company and callousness of the military government in devastating their environment. Amidst untold hardship owing to the destruction of sources of livelihood, the Sibeye boys protest for the need to ensure safer environment in the region and reclaiming the oil which rightfully belong to them and their being short-changed by the Western Oil Company for their own selfish benefits.

In the light of ecological degradation and resultant crisis in the Niger Delta environment, Watson presents the need for the preservation of life of birds in the novel. The novel captures the foreign oil operative, Dan, who possesses the spirit of activism against possible decimation of birds by any form of human activities in the environment. He is a bird enthusiast who has ornithology club with an intention to instilling the consciousness of bird conservation among the local people. Even when Alhaji discredits the bird watching as being irrelevant owing to some political matters in Nigeria, Dan stands firmly on his ground for what he believes is the right cause (166). The idea of Dan in promoting quality participation of bird watching and conservation by the local people is very paramount due to great prospects that such dispositions hold to the development of tourism in Nigeria. Furthermore, Watson presents Ezekiel as one of the strong voices of activism against the environmental injustices and its impact on the Niger Delta environment. Owing to the situation that beclouds the Niger Delta region, Ezekiel's sense of innocence is also affected likewise his environment. Ezekiel faces self-degradation from the circumstances which the Western Oil Company and military government have placed the Niger Delta region into. He is a victim of misfortune owing to miserable environmental degradation which dampens his dream of becoming a medical doctor. He supports the ideology of the Sibeye boys and joined the gang in the struggle in reclaiming their land from the shackles of exploitation and degradation by the oil company and military government. Ezekiel has strong hatred on the Western Oil Company and their exploitative activities in the region. He transfers aggression to Dan who is in a romantic affair with his mother (178). This display of activism by Ezekiel is not only predicated on his hatred on Dan's interest to marry his mother rather it is a pile up of aggression over the terrible activities of the oil companies in the Niger Delta environment.

In the same light of activistic mindset, Alhaji is also shown as a character who believes on liberal or diplomatic approach of activism towards the despoliation of his immediate environment. He sees the pollution of the environment through oil exploration activities as a surmountable challenge. Alhaji puts it, "I will be 
preserving the environment by teaching my less polluting methods of oil refining. No more gases burnt into our air. The crops will grow. And the black bark of the avocado pear tree, which is very worrisome indeed, will disappear" (210-211). This approach is void of radicalism. Watson creates liberalism in the character of Alhaji with the consciousness to preventing any environmental injustices by the oil companies in polluting the air with its adverse effects on fruits for human consumption through quality preservation. It is worthy to note that Alhaji's liberal approach towards the plight of the Niger Delta environment is quite different from that of the Sibeye boys. While the former is liberal in nature, the latter sought for violence as a means of driving home their demand against the evils of the oil company in the region. Grandma is apt in her opinion on the issues that incite the violent actions of Sibeye boys. She admits that, "the oil companies are taking billions of dollars from our land. They know it's not theirs to take.... 'So they let us busy ourselves killing each other. And they let us think we have a way of taking back what is ours by kidnapping those oyibos" (236). The boys do not only engage in kidnapping the foreign oil operatives, they also break oil pipelines as a form of displaying their grievances against the Western Oil Company. It is on this violent activity of breaking pipelines that claim the life of Ezekiel and other young members of the group. Watson equally presents women and their role in the vanguard of fighting against the atrocities of the Western Oil Company and military government in the Niger Delta region. The women see the need to ensure peace and safe environment in the Niger Delta region and they stand firmly towards its actualization. They organized nude protest to show the extent of their concerns on the exploitative activities and degradation being unleashed on their environment and the local people by the oil company in their different communities (263-265). It is through the said nude protest that brings to limelight issues of environmental degradation, lack of social amenities, internal war and unemployment that emanate from the negligence of the Western Oil Company in fostering their own selfish gain in the region.

\section{Unmasking Politics of Eco-Degradation and Activism in both Texts: Comparative Analysis}

Another interest of this paper is to carry out a comparative analysis of Ojaide's The Activist and Watson's Tiny Sunbirds Far Away in order to identify areas of similarities and differences in the discourse of ecological degradation and activism. The justification of this comparative examination of both texts is based on the interests of Ojaide and Watson as both 'insider' and 'outsider' respectively, existing from different socio-cultural milieu and literary backgrounds with diverse ideas and exposure that possibly characterize their fictional representation of the Niger Delta environment. In other words, it also anchors on the engaging view of "literature [especially about the Niger Delta environment] beyond the confines of one particular country...and its comparison with other spheres of human expression" (Remak 1973: 3).

The nexus which exists in both texts under study is very significant owing to the nuances that emanate from degradation of the environment and its impacts which they succinctly capture in similar ways. Despite the distinction in locality of Ojaide and Watson as Nigerian and British writers respectively, they share same literary setting of the Niger Delta environment and its culminated activism among characters in both novels. This similar focus of both writers and thematic preoccupations of their works justifies the words of Izevbaye (1982) of "having similar aesthetics and social function" (11). It is interesting to note that oil exploration activities by multinational oil companies form the centre stage in the utter despoliation of the Niger Delta environment in both texts. Ojaide and Watson x-ray the unhealthy environmental practices of the Bell Oil Company and the Western Oil Company in different capacities. The true state of degradation of place and characters is exemplified in the two novels which affects the pristine existence of both living and non-living things in the environment by the oil companies. It is from this sense that one can appreciate the environmentally conscious characters of the Activist, Ebi, Pere, Chief Ishaka and Omagbemi as well as dispositions of Blessing, Ezekiel, Alhaji and Grandma in the Niger Delta settings as being presented by Ojaide and Watson respectively.

The two texts explore issues of youth restiveness as part of activism against harmful activities in the Niger Delta environment being perpetuated by the oil companies. This restiveness is a product of degradation of innocence of the vulnerable youths who are subjected to alienation, unemployment and penury. In extreme cases, these ugly situations lead to all manner of formation of rebel groups that engage in social vices like stealing, oil bunkering and kidnapping of oil expatriates as an avenue of advancing the cause of restoring the Niger Delta region from environmental injustices being done by the multinational oil companies. In The Activist, the "Area boys" constitute youths who are victims of misfortune, as they take up violence due to negligence and abject poverty emanating from the degraded environment of the Niger Delta State. In the wake of same experience, there is equally a replica of incident of youth restiveness in Tiny Sunbirds Far Away as "Sibeye Boys" carry out their dubious activities with intent to frustrating the exploitative progress of the oil company. It can be deduced from the activism of both rebel youthful groups in the two texts are purely radical owing to the tragedy they unleash in their fight against the evil exploitation of the oil companies in the Niger Delta region.

Moreover, the need to agitate against the degradation of the environment by multinational oil companies ushers in similar sense of activism among women in both texts under study. The women see the need to putting to an end any form of environmental degradation towards ensuring a safer Niger Delta environment. The Activist 
presents actions of women in voicing out their grievances against hazardous activities by the Bell Oil Company in the Niger Delta State. The desire to undermine the coercive force and degrading activities of the oil company stirs the enlightenment campaign by Ebi and Mrs Taylor in soliciting support of other women mostly from polluted oil producing communities to rise in the fight for a new environment free from oil spillage, gas flaring and blowouts. Same situation is seen in Tiny Sunbirds Far Away where the women organize a nude protest which the Bell Oil Company and the military government halted and they are assaulted sexually with recorded death of some victims in such ill-fated protest.

It is worthy of note that the activism in the Niger Delta region of both texts is not only found within the confines of the local people who feel exploited in the context of environmental degradation by the oil companies. The Bell Oil Company and Western Oil Company as shown in both novels devise violent means in retaliation against any manner of protest by the local people. This becomes achievable through the collaboration by the federal military government. Ojaide showcases the callousness of the Bell Oil Company who establishes violent group in suppressing the vulnerable local people who are kicking against their evil activities in the region (27). Watson also presents the Western Oil Company like the Bell Oil Company in The Activist, as they take delight in oppressing the local people especially when the latter, protest for the reclaim of their oil. The Western Oil Company establishes the Kill and Go Police to massacre protesting villages and people in their fight against their activities in the region which lead to massive killings in the region and destruction of property of the local people including animals (113).

It is therefore, pertinent to examine both novels in order to explore their points of differences in the discourse of ecological degradation and activism. The production of both literary works, even with same environmental concern and setting by the authors, totally differs in their manner of presentation and communication of thoughts. Undoubtedly, there is always a disparity in style between two writers despite exploring same thematic preoccupation. This dichotomy in presentation of ideas by writers lends credence to the view of Osundare (2008: 13) that "the nature of style and literary communication is depended upon social vision and ideological mission of the writer". There is no gainsaying the fact that apart from oil exploration activities by multinational oil companies which form the centre of attraction in both texts, there are traces of other harmful activities done by local dwellers in the despoliation of their own environment. Those harmful activities basically happen out of sheer ignorance, superstitious belief or as a means of deriving pleasure among characters. Tiny Sunbirds Far Away captures those other harmful activities against the environment as done by local dwellers on their own ignorant accord which are not exposed in The Activist. Based on the textual analysis of the novel, Ojaide is obviously interested on the politics of oil and deeds of the oil companies in the despoliation of the Niger Delta environment. One begins to think the objective account of the degraded region without the contribution of the local people in the same environment which Ojaide on his own sentimental stance, refuses to put into serious consideration in his fictional representation. However, Watson's narrative of the Niger Delta environment is unbiased. She not only exposes the impacts of oil exploration activities but equally captures series of harmful actions of the local people in polluting their environment. Blessing's account on how the local people gather rubbish like plastic, wire, metal cans and broken bottles which Grandma confided in her that they are saved every year which they believed are washed down into the river by god (58) is really worrisome. In the same light, the novel further presents Blessing's interaction with Grandma as a revelation on how cultural or spiritual practice of the villagers in throwing dead witches and wizards into the river contributes to the pollution of river which is one of the basic needs of the people (69). The novel also explores other human-induced attitude against the life of trees. The actions of Celestine and Grandma in raising herself up high and suddenly jumped into the air, landing on a mango tree (88) and throwing of infected afterbirth in a large fire in the village (114) respectively, are evident in the despoliation of the Niger Delta environment.

There is a gap in the presentation of motives behind the role of women in kicking against the degradation of their environment in both texts. The interrogation of the nude protest by women against the multinational oil companies shows diverse representation of notions in respect to women and their concerns in the despoiled Niger Delta environment. The Activist presents significant impacts of the oil exploration activities in the environment especially on the lives of women as one of the major reasons behind the planned nude protest. The toxic substances which pollute the environment as a result of oil exploration activities make it difficult for women to conceive and in most cases; pregnant women deliver malformed babies including all manner of health hazards (239-241). Ojaide is very sympathetic on the plights of women in the region. He is indirectly instilling the eco-feminist consciousness among women in reclaiming their right of healthy living and survival amidst the degradation of the Niger Delta environment by the oil companies. In total contrast, the protesting role of women in Tiny Sunbirds Far Away fails to capture distinctively the special effect of environmental degradation on women as a major propelling force behind their nude protest against the Western Oil Company. The women are majorly interested in the general welfare of the Niger Delta people. They demand good hospitals, an environment free from pollution, the defunding of military government, unemployment, free-violence in the region and total rehabilitation of their children who have joined Sibeye boys due to lost of their sense of 
innocence in the despoiled environment. Furthermore, the two texts also vary in the representation of women in the course of survival amidst environmental degradation. There are issues of women whose innocence are also degraded and as such become vulnerable as a result of poor state of living based on negative impacts of oil exploration activities in their environment which are being perpetuated by the oil companies. Apart from Ebi and her like-minds, some of the female characters in The Activist are presented as prostitutes satisfying the sexual urge of the oil exploiters as a means of survival (241-242). Divergently, in Tiny Sunbirds Far Away, Watson presents formidable female characters such as Mama as a single parent, Celestine as a funeral bearer, Grandma as birth attendant and Blessing working as an assistant birth attendant. These women, above all challenges and hardship owing to the effect of environmental degradation in the Niger Delta environment, strongly uphold their sense of morality and succeed in making ends meet through hard work and self-development.

Obviously, approaches of activism against the despoliation of the environment by the oil companies are quite oppositional in both texts. There is a liberal approach of activism towards oil exploration activities in Tiny Sunbirds Far Away. This manifests in the character of Alhaji who sees the need to adopt careful and pragmatic measures in the exploration of oil in the environment as the most civil means of ensuring a clean Niger Delta environment (90). This manner of environmental approach in ensuring safe environment contradicts the radical, political and long term basis of activism (education) which are evident among characters such as the Activist, Pere, chief Ishaka and Omagbemi and their activities in The Activist as the part of the ways in staging a struggle against the devastation and exploitation of the environment by multinational oil companies. There is an endearing vision for the conservation of birds in the environment in Tiny Sunbirds Far Away through passionate actions of Dan despite being a foreign operative of the oil company. Watson presents him as a visionary character in strengthening the existence of birds against devastation through unguided activities of humans in the environment. The existence of birds in a free polluted environment is Dan's utmost drive of activism which he believes can be conserved even in the gradual devastation of the environment especially in the Niger Delta region. Dan's activism on the need to imbibing the spirit of bird watching amidst Alhaji's debasement of such action as being irrelevant is quite civil in all ramifications. It is clear that his disposition for creating awareness on the immense benefits of conserving birds in the environment has the prospect of developing tourism industry in Nigeria thereby increasing the country's economy (147-166). Unlike Watson, Ojaide fails to explore this type of ecological activism and vision towards conservation of birds and its economic relevance in the Niger Delta environment in The Activist.

Significantly, the main thrust of eco-activism in The Activist is quite revolutionary in nature. The vision of ensuring independent drilling of oil by the oil producing communities themselves is totally absent in Tiny Sunbirds Far Away. Ojaide remarkably fuses such visionary tactics in the choice of Chief Ishaka who sees the importance of education as one of the long term plans in solving the problem of the degraded Niger Delta environment. In this regard, he sends his son, Dennis, to study Petroleum Engineering in the university. This gradual revolutionary intention is geared towards off staging the white explorers as part of the tactics set aside to secure safe environment in the Niger Delta State. Ojaide creates the progressive character in Chief Ishaka in advocating the cause of having oil exploration activities being done by indigenous engineers alone in order to avert pollution of their environment as part of the future plans in restoring the lost glory of the Niger Delta region. Dissimilarly, this very futuristic and revolutionary vision of activism is not capture among characters in the fight against the activities of Western Oil Company in their environment as represented in Tiny Sunbirds Far Away. Ojaide in The Activist also presents the acquisition of political and media powers as some of the ways in actualizing the vision of activism towards undermining ecological imperialism by the oil companies in the Niger Delta environment. This vision becomes achievable through joint efforts of the Activist, Pere, Ebi, Omagbemi and other progressive characters in the novel. These characters work harmoniously to defeat exploitative forces of the Bell Oil Company and military government and take up the role of self-governance towards alleviating their peoples' suffering and ensuring a greener environment in the Niger Delta State. The Activist contested and won the governorship position of the Niger Delta State and uses his political position to drive home his mission of developing the region free from oil pollution. In total contrast, Tiny Sunbirds Far Away does not capture acquisition of political and media powers in the struggle against the fight against environmental degradation and imperialistic tendency of the Western Oil Company in its Niger Delta environment.

\section{Conclusion}

Based on the above findings of this study, it is therefore pertinent to conclude that the comparative analysis of Ojaide's The Activist and Watson's Tiny Sunbirds Far Away indicates glaring points of similarities and differences as regards the representation of ecological degradation and activism. As have been demonstrated in the analysis of both novels, it can be deduced that the environmental degradation of both places and characters is primarily induced by oil exploration activities of multinational oil companies alongside other ignorant and superstitious attitudes of some local dwellers. The aesthetics of both texts manifest in proffering diverse visions of eco-activism among characters ranging from liberal, civil, revolutionary, conservative to radical approaches as 
means of ensuring a safer environment and putting to an end to exploitation of the affected people by the machineries of the oil companies and unguided local people. Thus, both writers used their individual novels as additional voices towards the promotion of global environmental conservation especially in the Niger Delta region.

\section{References}

Agbasiere, J. (2000). African Literature and Social Commitment. Opata, D.U and Ohaegbu, A.U (Eds.), Major Themes in African Literature (pp. 71-83). Enugu. AP Express Publishers.

Alagoa, E. J. (2011) Foreword. Oil Wars in the Niger Delta (1849-2009). By Tekena. N. Tamuno. Ibadan: Stirling-Horden Publishers Ltd.

Glotfelty, C. (1996). Literary Studies in an Age of Environmental Crisis. In Glotfelty. C and Fromm. H (Eds.), The Ecocriticism Reader: Landmarks in Literary Ecology (pp. xv-xxxvii). Georgia: University of Georgia Press.

Izevbaye, D. (1982). The African Experience of Comparative Literature. In Essien, S.O (Ed.), Comparative Approaches to Modern African Literature (10-25). Ibadan: Ibadan University Press.

Nwahunanya, C. (2011).Ed. From Boom to Doom-The Niger Delta in Contemporary Nigerian Literature. From Boom to Doom: Protest and Conflict Resolution in the Literature of the Niger Delta (pp. xiii-xxi). Owerri: Springfield Publishers Ltd.

Ojaide, T. (2006). The Activist. Lagos: Farafina.

Olughu, M. I. (2018). Ecological Degradation and Activism in Tanure Ojaide's The Activist and Christie Watson's Tiny Sunbirds Far Away. Unpublished Master's Project, University of Nigeria, Nsukka.

Onukaogu, A. A, \& Onyerionwu, E. (2009). $21^{\text {st }}$ Century Nigerian Literature: An Introductory Text. Ibadan: Kraft Books Ltd.

Osundare, N. (2008). Style and Literary Communication in African Prose Fiction in English. Ibadan: Hope Publications Ltd.

Remak, H. L. (1973). Comparative Literature: Its Definitions and Functions. In Stalknacht. N and Frenz. H(Eds.), Comparative Literature, Method and Perspective (3-37). Carbondale: Southern Illinois University Press.

Rueckert, W. (1996). Literature and Ecology: An Experiment in Ecocriticism. In Glotfelty. C and Fromm. H (Eds.), The Ecocriticism Reader: Landmarks in Literary Ecology (105-123). Georgia: University of Georgia Press.

Thiong'o, N. (1972). Homecoming: Essays on African and Caribbean Literature, Culture and Politics. London: Heinemann.

Watson, C. (2011). Tiny Sunbirds Far Away. Lagos: Cassava Republic Press. 